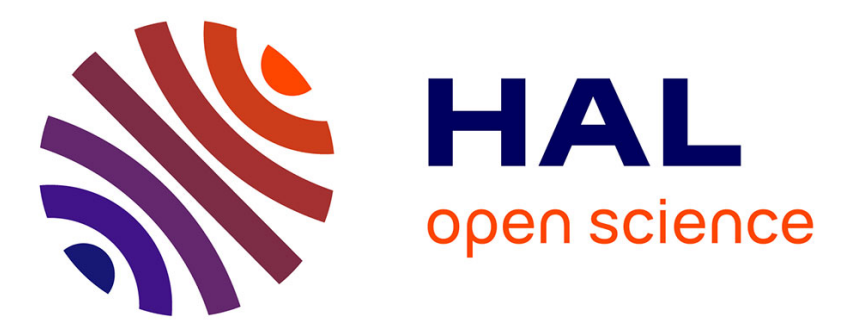

\title{
Analysis of systematic errors in Mueller matrix ellipsometry as a function of the retardance of the dual rotating compensators
}

L. Broch, A Naciri, L. Johann

\section{- To cite this version:}

L. Broch, A Naciri, L. Johann. Analysis of systematic errors in Mueller matrix ellipsometry as a function of the retardance of the dual rotating compensators. ICSE-V, 2010, Albany, United States. 2010. hal-02901802

\section{HAL Id: hal-02901802 \\ https://hal.univ-lorraine.fr/hal-02901802}

Submitted on 17 Jul 2020

HAL is a multi-disciplinary open access archive for the deposit and dissemination of scientific research documents, whether they are published or not. The documents may come from teaching and research institutions in France or abroad, or from public or private research centers.
L'archive ouverte pluridisciplinaire HAL, est destinée au dépôt et à la diffusion de documents scientifiques de niveau recherche, publiés ou non, émanant des établissements d'enseignement et de recherche français ou étrangers, des laboratoires publics ou privés. 
